\title{
Entering the Union:
}

\section{European Accession and Capacity-Building Priorities ${ }^{+}$}

\author{
John S. Wilson ${ }^{*}$ Xubei Luo ${ }^{* *}$, and Harry G. Broadman ${ }^{* * *}$
}

\begin{abstract}
This paper examines the impact of trade facilitation on bilateral trade flows. We examine trade facilitation and capacity building priorities in 12 countries in the Europe and Central Asia region - eight of the current members of the European Union: Czech Republic, Estonia, Hungary, Latvia, Lithuania, Poland, Slovakia and Slovenia and three candidate members: Bulgaria, Romania, and Turkey. Our results suggest that behind-the-border factors play an important role in determining bilateral trade flows (controlling for the effects of tariffs, development levels, distance, and regional characteristics of exporters and importers, among other factors).

The development of new data sets to expand work related to trade facilitation, including strengthening the empirical work explored here is a key priority without which intelligent policy and priorities cannot be made. Our analysis is based on data from the World Economic Forum, Global Competitiveness Report 20012002, World Competitiveness Yearbook 2000, and Kaufmann, Kraay and Zoido-Lobaton (2002). The results outlined here indicate that more gains in exports than in imports are expected should the values of three out of the four indicators (port efficiency, regulatory regimes and IT infrastructure) ${ }^{1}$ of the new and candidate member countries improve halfway to the EU15 average. These countries would expect large trade gains as well as improvements in trade balances as their integration into the EU continues. For example, the greatest absolute trade gains - $\$ 49$ billion and $\$ 62$ billion respectively - could be expected if their port efficiency and IT infrastructure reach half the average level of the $\mathrm{EU}$, and $70 \%$ of trade gains are associated with export expansion.
\end{abstract}

\section{World Bank Policy Research Working Paper 3832, February 2006}

The Policy Research Working Paper Series disseminates the findings of work in progress to encourage the exchange of ideas about development issues. An objective of the series is to get the findings out quickly, even if the presentations are less than fully polished. The papers carry the names of the authors and should be cited accordingly. The findings, interpretations, and conclusions expressed in this paper are entirely those of the authors. They do not necessarily represent the view of the World Bank, its Executive Directors, or the countries they represent. Policy Research Working Papers are available online at http://econ.worldbank.org.

\footnotetext{
${ }^{+}$The research results presented here are part of a broader research project on "Trade Facilitation and Economic Growth: The Development Dimension" in the Development Economics Research Group of the World Bank. The project is funded through a Trust Fund established by the U.K. Department for International Development (DFID) to explore the impact of trade costs and barriers on development. The findings and conclusions here do not necessarily represent the views of U.K. government or DFID.

* Development Research Group, World Bank, 1818 H Street, NW, Washington, DC.

${ }^{* *}$ Europe and Central Asia Region, World Bank. Corresponding email: xluo@worldbank.org.

*** Africa Region, World Bank.

${ }^{1}$ See Annex 1 for the definition of the four indicators "port efficiency", "customs regimes", "regulatory policy”, and "IT infrastructure". It will be of benefit to include additional indicators (such as road quality, etc.) in the analysis. However, subject to data constraints for cross-country comparisons this is not possible currently.
} 


\section{Introduction}

Understanding the relationship between economic development and the transportrelated costs of international trade is relatively straightforward in theory. Analysis of how, in practice, modern trade logistics influence the facilitation of international commerce, however, is more challenging in empirical design and estimation: the linkages between the two are multifaceted, subtle and complex. Economic development and poverty alleviation are both achieved through income growth. We also know-from an increasing body of empirical evidence - that economic growth expands with world trade. Lower transport and other traderelated transactions costs, in turn, provide the engine through which trade expands to achieve development goals.

The traditional definition of "trade facilitation" centered on ways to achieve lower international transport costs. In modern commerce, however, a broader definition is called for: today, facilitating trade involves not only improved efficiency in logistics at ports and customs - through greater transparency, ensuring operational decisions are rules-based (rather than discretionary), and the use of advances in technology (including but not limited to IT), among other things - but also streamlined regulatory policy, deeper harmonization of standards, and conformance to international norms so that overall transactions costs are lowered (Woo and Wilson, 2000; Wilson et al., 2002). Indeed, reducing the "behind the border” barriers associated with achieving the goal of lowering transactions costs through domestic reforms is increasingly at the center of international policy deliberations in governments of transition economies and developing countries, among donor agencies, and in regional and multilateral trade negotiating forums.

In the transition countries of Europe, CIS and Central Asia-hereafter "ECA"reducing such barriers is increasingly seen as the key policy priority to accelerate integration into the world economy, including through accession to the World Trade Organization (WTO) and membership in the European Union (EU). Thus, many ECA countries are faced with the increasingly broader challenge of facilitating trade through moving goods through ports more efficiently by streamlining the movement of documentation, enhancing the professionalism of customs officials, harmonizing product and technical standards with 
international or regional regulations, and strengthening the integration of new technologies into the transport and communications infrastructure.

Meeting these "domestic" international trade facilitation challenges places enormous importance on the need for capacity building. As countries-and the international donor community-decide on how best to deploy resources for such capacity-building a critical policy question arises: What is the relative impact of improvements in trade facilitation in contrast to gains from lowering traditional trade barriers, such as tariffs and quotas? Trade facilitation was added to the policy dialogue on trade issues at the Singapore Ministerial of the WTO in 1996.

In August 2004, the WTO decided to focus part of the negotiations currently underway in the Doha Round on trade facilitation issues. As a result, today, trade facilitation discussions are at the center of the Doha Development Agenda. The European Union, among others, has been a leading advocate of such negotiations. At the same time, regulatory reform, modernization of customs regimes, and infrastructure investment related to lowering trade logistics costs are key components of development strategies for the new members of the EU and those in line for accession. Clearly, then, earmarking sufficient resources-both financial and human — to build the requisite institutional capacity in order to implement trade facilitation reforms is increasingly an important policy issue for governments.

There are a number of important challenges in carrying out empirical research on the impact of trade facilitation initiatives to help inform policy decisions and capacity-building priorities. They include selecting the most appropriate measures to gauge the extent of trade facilitation, identifying a suitable modeling methodology to estimate the impact of trade facilitation on exports and imports, and establishing an analytical framework to estimate the effect of improved trade facilitation on trade flows.

This paper builds on Wilson, Mann, Otsuki (2005) [hereafter WMO (2005)] and uses four separate indicators to estimate trade gains due to trade facilitation progress in (i) port efficiency, (ii) customs regimes, (iii) regulatory policy and (iv) information technology 
infrastructure for new member and candidate members of the European Union. ${ }^{2}$ We also provide policy suggestions on the priorities in trade facilitation improvement. ${ }^{3}$

\section{Trade and Regional Integration in Europe: Empirical Analysis for Capacity Building}

The new members of the European Union-Cyprus, Czech Republic, Estonia, Hungary, Latvia, Lithuania, Malta, Poland, Slovakia and Slovenia-now have more direct access to regional markets. Four candidate EU members-Bulgaria, Croatia, Romania, and Turkey-are preparing the groundwork for accession. The reduction in tariffs, quotas, and other traditional steps toward integration are only part of the measures both groups of countries are introducing. Measures are also being put in place to enhance port efficiency, improve customs regimes, reform regulatory policies, and develop the information technology infrastructure.

Conventional gravity model analysis suggests that transactions costs impede the exchange and the transfer of goods and services from different countries/regions. The wedge between export and import prices reduces profit margins. In particular, trade barriers -- both tangible and intangible -- limit trade and slow prospects for regional development. According to Overman et al. (2001), access to foreign markets alone could explain some 35\% of the cross-country variation in per capita income. Regions with higher transactions costs exhibit slower growth (Diamond, 1997; Limao and Venables, 2001; Redding and Venables, 2003).

Importantly, with advances in technology, transport costs have become less subject to distance. Hummels (1999) suggests that while in 1974, shipping commodities over a distance of $9000 \mathrm{~km}$ by sea was approximately 60\% more expensive than shipping over a distance of $1000 \mathrm{~km}$. The cost difference was reduced by a half (to 30\%) by 1998. Given that the new members and candidate members of the EU are relatively physically far from the central

\footnotetext{
${ }^{2}$ See Annex 1 for the definition of the four indicators "port efficiency”, “regulatory policy”, and "IT infrastructure". It will be of benefit to include additional indicators (such as road quality, etc.) in the analysis. However, subject to data constraints for cross-country comparisons this is not possible currently.

${ }^{3}$ The results outlined in this paper will be referenced in a publication forthcoming by the World Bank in a new book entitled, From Disintegration to Re-Integration: Eastern Europe and the Former Soviet Union in International Trade, Harry Broadman, ed).
} 
markets of the EU, this reduction in long-distance transport costs would tend to facilitate trade significantly, all other things equal. This reduction in "effective distance" raises even further the relative importance of lowering the transactions costs of trade.

Integration into the EU will, over time, clearly engender enhanced trade facilitation. EU membership will make it possible to move goods freely between member states without the need to complete formal import and export documentation or pay import VAT or customs duties. This should result in a more rapid movement of goods (and services) between member states and reduce transactions costs. The harmonization and implementation of the acquis communautaire also require new member countries to make major improvements in their overall economic environment-both at the border and behind the border.

On a global basis, the estimates by WMO (2004) suggest that improvements among the four dimensions of trade facilitation that are the focus of this paper-port efficiency, customs regimes, regulatory policy, and information technology infrastructures-can lead to significant trade gains. Their analysis indicates that for the 75 sample countries, raising capacity halfway to the global average would yield a \$377 billion gain to world trade.

Our paper takes as the starting point the same analytical framework underpinning the global assessment but focuses on a subset of 12 ECA countries-eight of the current members of the EU: Czech Republic, Estonia, Hungary, Latvia, Lithuania, Poland, Slovakia and Slovenia (hereafter EU8); and four candidate EU members: Bulgaria, Croatia, Romania, and Turkey ${ }^{4}$. We also move beyond the evaluation of trade facilitation based on a single parameter, such as the price of imports, the productivity of the transport sector or the costs of transportation, and examine the four dimensions of trade facilitation noted above. We use a gravity model of bilateral trade flows for our estimations, rather than a computable general equilibrium (CGE) approach. The scenarios examined here do not assume that all countries in our sample (those that have acceded to the European Union or candidate members) improve capacity by the same amount. To keep our scenarios realistic, we assume that countries improve their trade facilitation capacity half-way to the EU15 level- the countries

\footnotetext{
${ }^{4}$ The data on port efficiency, customs regimes, regulatory policy and information technology infrastructures for Cyprus, Malta and Croatia are not available. Given the relatively small economic size of Cyprus and Malta, we focus on the study of the other eight new member countries of EU. Data for Croatia are not currently available.
} 
initially less developed in trade facilitation are assumed to make larger progress in absolute terms but we still keep the rankings across countries unchanged. Some ECA countries have further to go to reach best practice in regulatory reform or in port efficiency, for example, than do others.

\section{Description of the Database}

We utilize the database in WMO (2004). ${ }^{5}$ Our measures indicate how far a country's performance is from the best-practice country in each of the four trade facilitation dimensions. The best-practice country is indexed to a value of 1.0. Among the 75 sample countries in 2001, Singapore is the best performer in port efficiency and Finland is the best performer in the other three areas. For each country, the indicator "Port Efficiency" is an average of the efficiency of the port facilities / inland waterways and air transport; ${ }^{6}$ the indicator "Customs Regimes" captures the hidden import barriers other than published tariffs and quotas, and the irregular extra payments or bribes connected with import and export permits; the indicator "Regulatory Policy" is constructed as the average of the transparency of government policy and the control of corruption; and the indicator "Information Technology Infrastructure" is measure of the speed and cost of internet access and the contribution of internet to the reduction of the inventory cost.

\section{Cross-Country Comparisons in ECA}

The 15 EU member countries (EU15)—-the members that existed prior to May 2004are relatively advanced in all four areas, with an average value of $0.82,0.87,0.79$, and 0.78 in port efficiency, customs regimes, regulatory policy, and information technology infrastructure, respectively. ${ }^{7}$ The development level of trade facilitation in the EU15 ranks well on average; with customs efficiency rated the highest.

The new EU8 member countries, however, are less developed in these four areas with an average value of $0.60,0.73,0.65$, and 0.64 , (development level of $72 \%, 83 \%, 81 \%$, $81 \%$

\footnotetext{
${ }^{5}$ See annex 1 for a summary of the statistics and data sources of the four trade facilitation indicators.

${ }^{6}$ Due to the data constraint, we could not measure the efficiency of the port facilities and inland waterways separately.

${ }^{7}$ The data for Luxembourg is not available. We use the average of the other 14 member countries as that of EU 15.
} 
of the EU 15 respectively, see Figure 1). As to three candidate members (Bulgaria, Romania and Turkey), the development of their trade facilitation is further behind, with the state of their customs regimes the furthest behind-58\% level of the EU15.

The level of development of the new and candidate member countries varies most in port efficiency - Estonia and Latvia are the best performers with a development level around $70 \%$ of the best performers. The Slovak Republic and Bulgaria are at a level less than $50 \%$ of the best performers. Regarding IT infrastructure, Estonia performs well (reaching the level of $80 \%$ of the best performer), followed by the Czech Republic, Slovenia, Slovak Republic, and Romania (around 65-70\% of the best performer). Estonia and Hungary have the highest benchmark in customs efficiency. As to regulatory policy, the development levels of the new and candidate member countries tend to be less heterogeneous.

Figure 1 Comparison of New and Candidate EU Members and the EU15

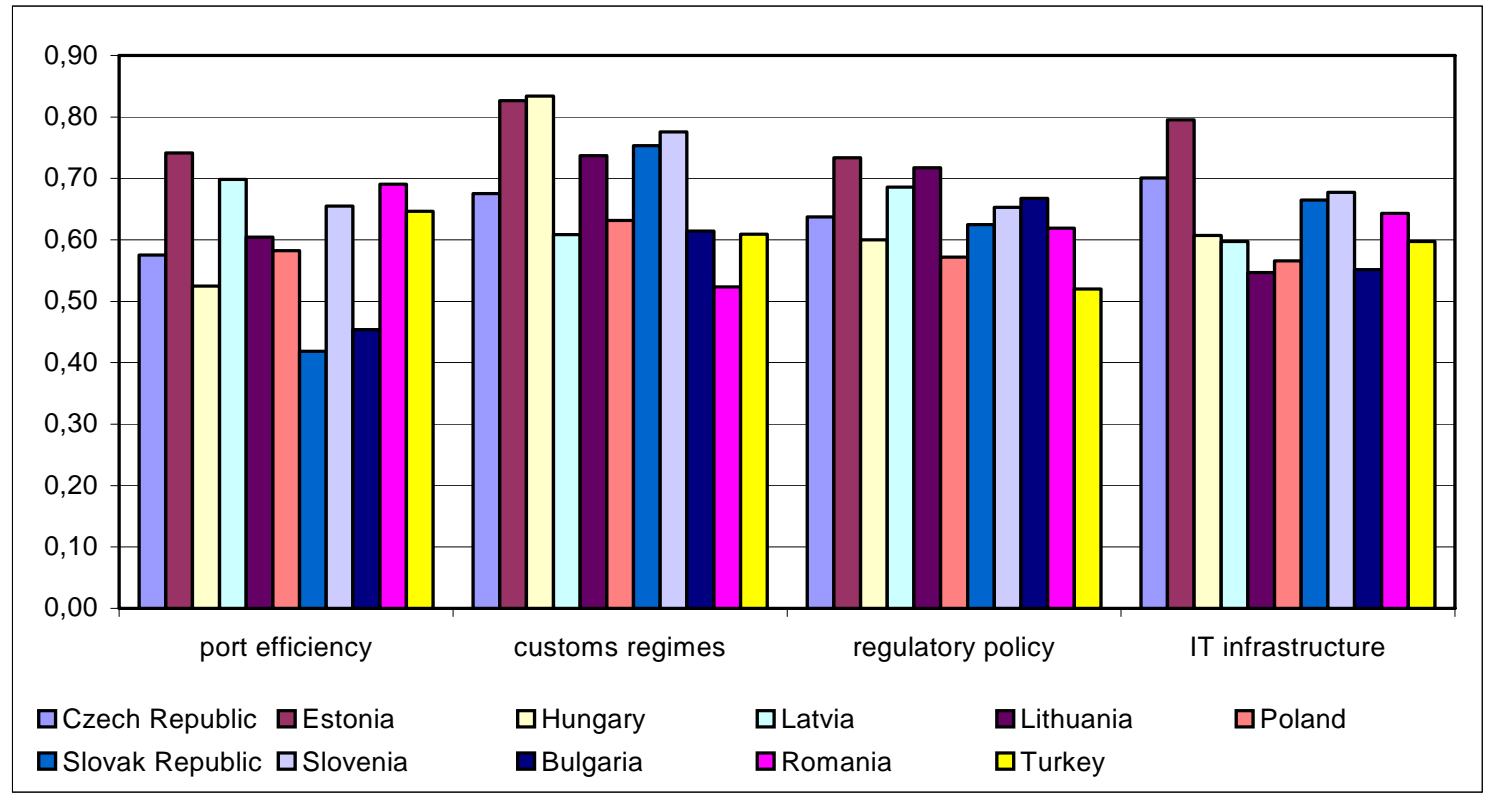

Figure 2 shows that the new member countries, for example the three largest economies (the Czech Republic, Hungary, and Poland), are not only less developed than the EU15 in trade facilitation as a whole, but also constrained in particular dimensions. Hungary's customs regime approaches 95\% of the EU15 level, while in ports efficiency it is about $60 \%$ of the EU15 level. The Czech Republic is relatively developed in IT 
infrastructure, which reaches almost 90\% of the EU15 level, while in port efficiency it is less than $70 \%$ of the EU15 level. Poland, the least developed among these three, exhibits a level in the four areas around $70 \%$ of the EU15 benchmark. In sum, the results suggest that in order to achieve the trade facilitation levels of the EU15, the new member countries face differing challenges.

Figure 2 New member countries (Czech Republic, Hungary and Poland)

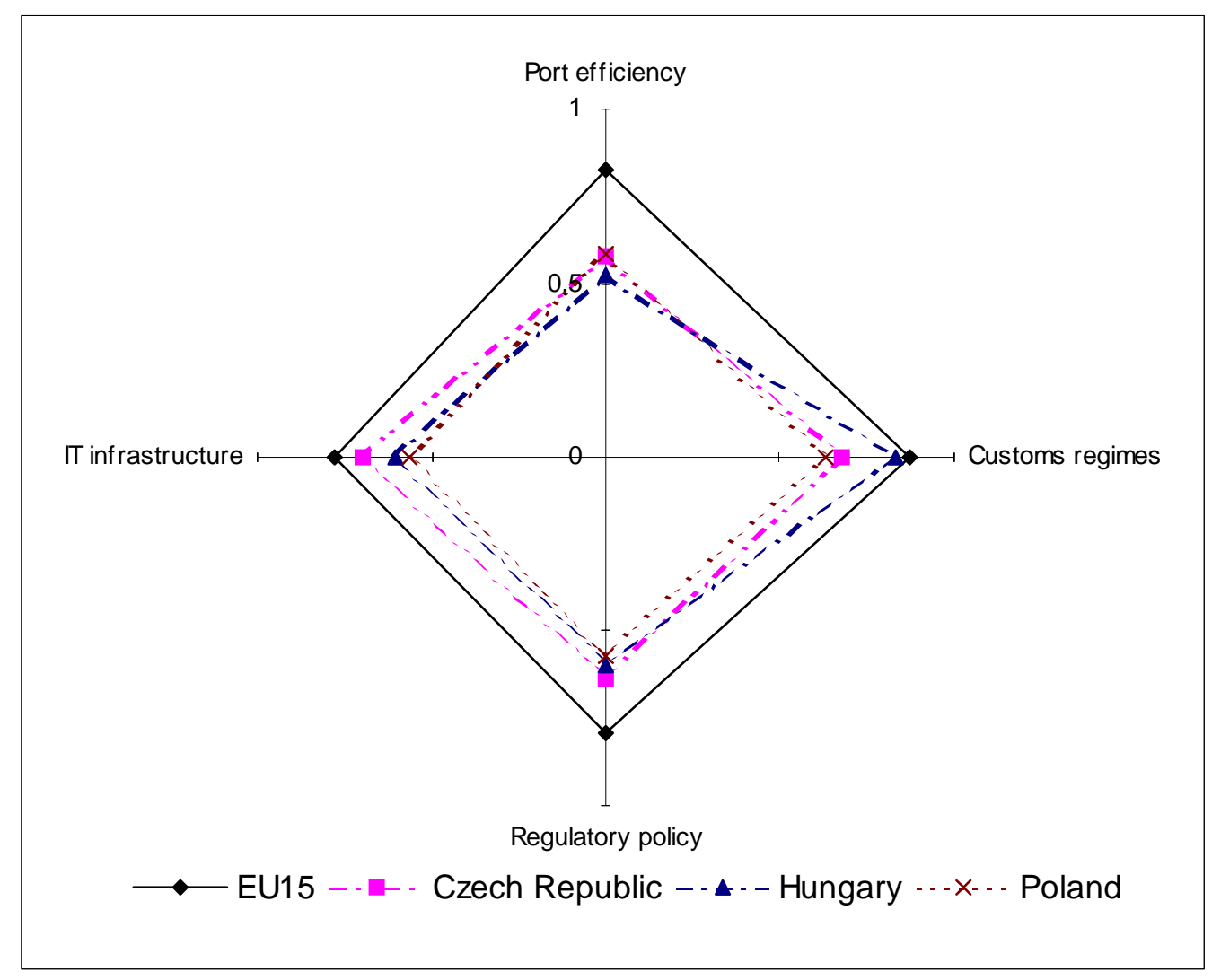

Figure 3 indicates a similar situation: the countries that are candidate EU members suffer from low trade facilitation development overall and individual specific constraints. Bulgaria does relatively well in regulatory policy, which reaches almost 85\% of the EU15 level, while its port efficiency index is less than 50\% of the EU15 level. Romania, which performs well in ports and in IT infrastructure, with development levels over $80 \%$ of the EU15, lags behind in customs performance. 
Figure 3: Candidate Members of the EU (Bulgaria, Romania, and Turkey)

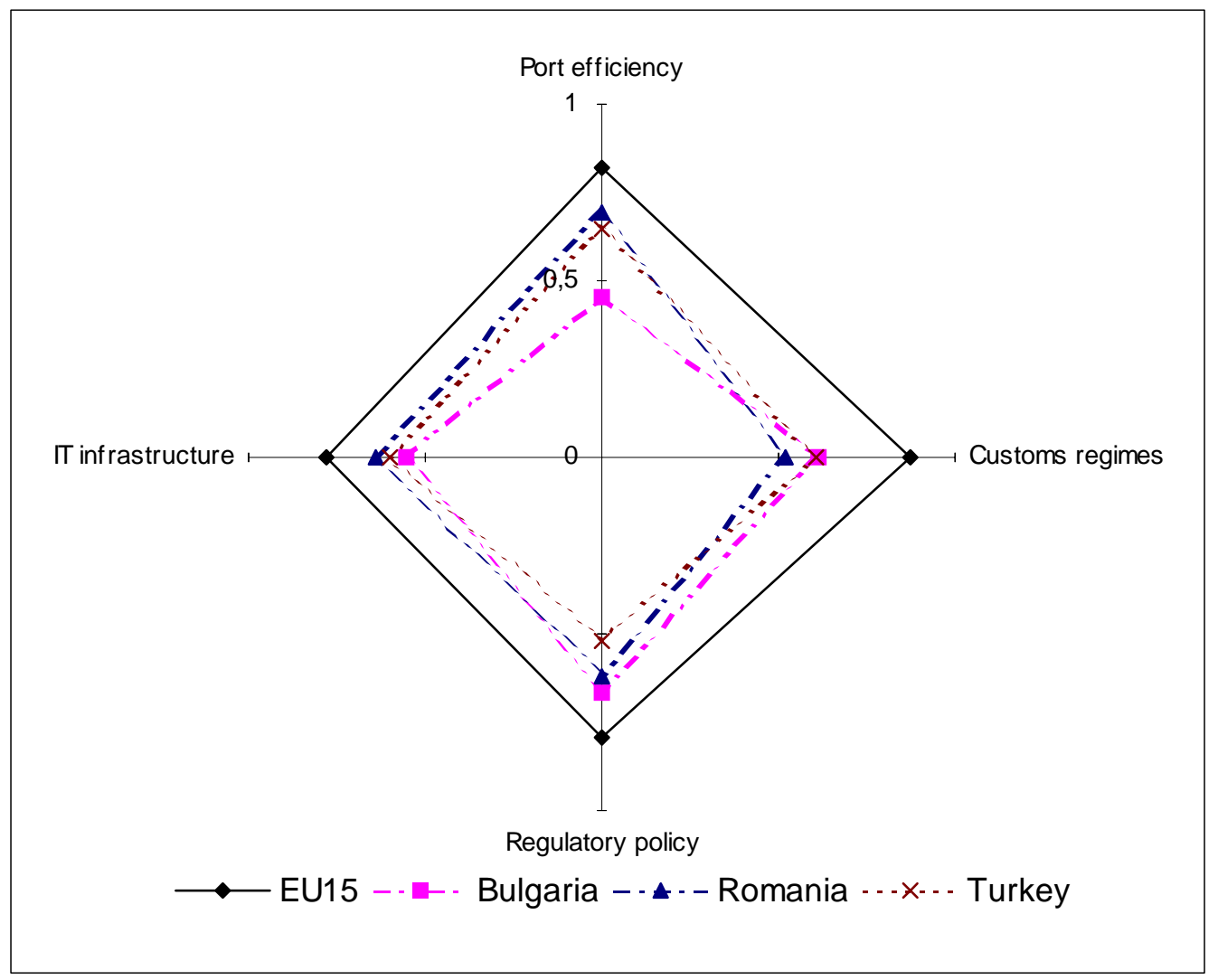

\section{Benchmarking the Relationship between Economic Development and Trade Facilitation}

The new members of the EU as a whole have exhibited rapid economic growth in the last several years despite the relatively weak performance of Western Europe and the world economy. Among the EU8, real GDP growth was approximately 2.5 percent in 2001 and 2002, and over 3 percent in 2003 (World Bank, 2004). Along with income convergence (though a large gap still exists), the EU8 have also made substantial progress in other fields such as in reduction in inflation. 
Does Economic Growth Enable Building Trade Facilitation Capacity? One assumes that economic growth and efficiency in trade facilitation are positively related. The more developed a country is, the more resources it can devote to investing in trade facilitation capacity. By the same token, it is likely that the larger the economy, the higher is the rate of return on investment in improving trade facilitation. This positive relationship between growth and trade facilitation indicators is confirmed by the data in the 75 sample countries the correlations between GDP per capita (adjusted by PPP) and port efficiency, customs regimes, regulatory policy, information technology infrastructures are respectively $0.78,0.86$, 0.68 and 0.81 .

The new and candidate members of the EU are less developed than the EU15. Does their gap in economic development account in some way for the lagged progress in their trade facilitation capacity? Considering GDP per capita, is the development of trade facilitation in the new and candidate members of the EU what would be expected? Our analysis of the data suggests that the new and candidate EU member countries are in general weak performers in all four of the trade facilitation dimensions examined (figures 4a-d). Indeed, even in the context of their relatively low of level of economic development, their trade facilitation development is relatively low, in fact under the benchmark level. The only exception is Estonia, which performs stronger than the benchmark level in all four indicators. Compared with Hungary, a country of a similar economic indicator, Estonia is $40 \%$ more developed in port efficiency, 30\% more developed in IT infrastructure and 20\% more developed in regulatory policy. ${ }^{8}$ In fact, the trade facilitation level of Estonia is even more developed than the average of EU15 in IT infrastructure. The strong growth in electronics and telecommunication sectors has likely contributed to the recent economic performance of Estonia - the real GDP growth rate was $4.8 \%$ in 2003, far above the regional average level. ${ }^{9}$

Figure 4a shows that, besides Estonia, three countries (Latvia, Romania, and Turkey) perform above their benchmark levels in port efficiency. The other new and candidate EU member countries are lagging behind; in particular, Slovak Republic and Hungary exhibit a

\footnotetext{
${ }^{8}$ Hungary and Estonia share the similar development level of customs regimes.

${ }^{9}$ For the sake of comparison, the real GDP growth rate of Hungary was 2.8\% in 2003 (data source: CIA Fact Book).
} 
lower degree of trade facilitation capacity despite their relatively high economic development level.

Figure $4 \mathrm{~b}$ shows that Hungary, Slovak Republic, and Lithuania—as well as Estonia— perform above their benchmark level in customs regimes. The other countries cluster close to the benchmark level. Figures $4 \mathrm{c}$ and $4 \mathrm{~d}$ show respectively similar phenomena as figures $4 \mathrm{~b}$ and 4a. In other words, apart from Estonia, many new and candidate member countries perform weakly in port efficiency and in IT technology—after taking their economic development level into account.

Figure 4a - Benchmarking to the value of GDP per capita (port efficiency)

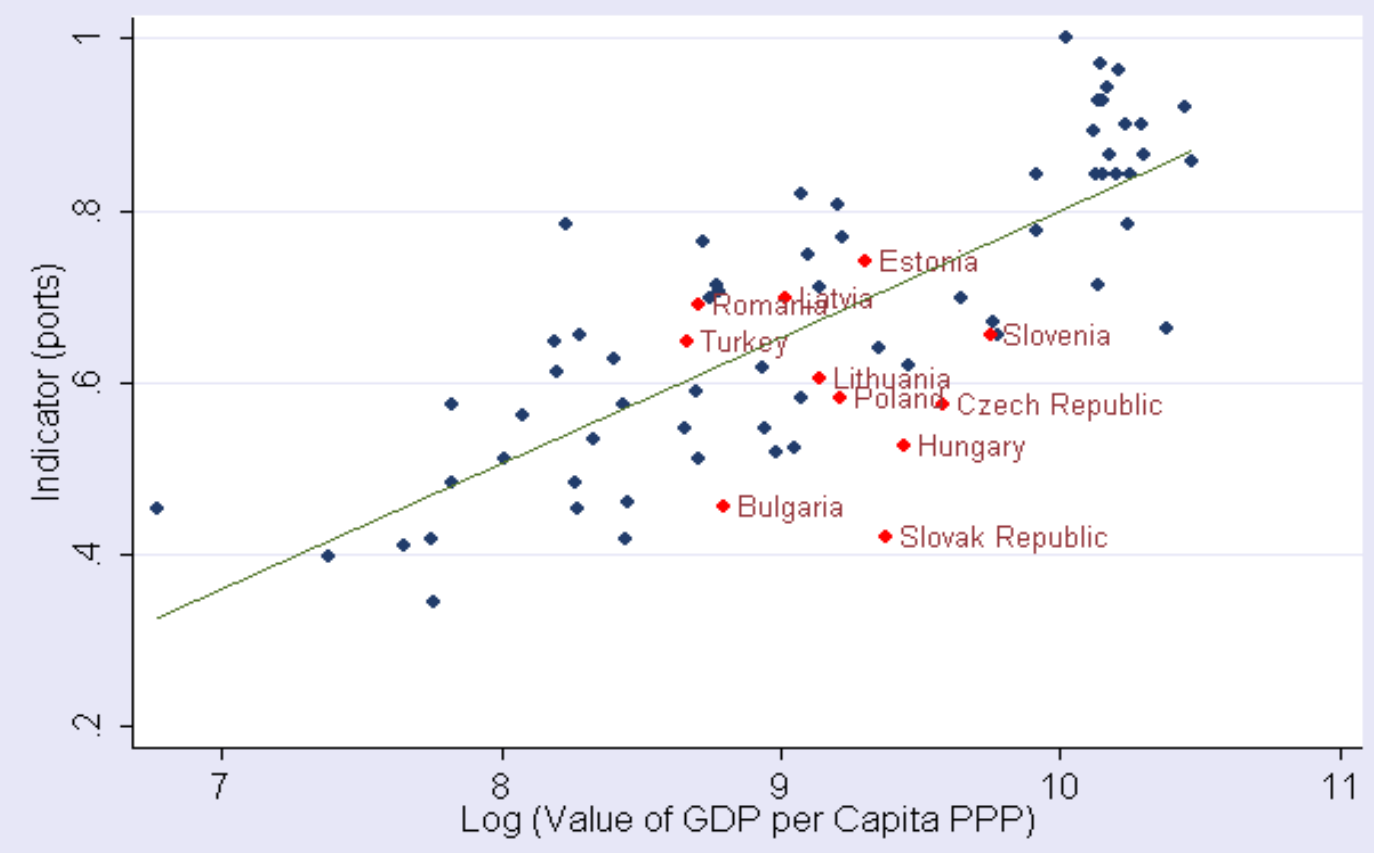


Figure $4 \mathrm{~b}$ - Benchmarking to the value of GDP per capita (customs regimes)

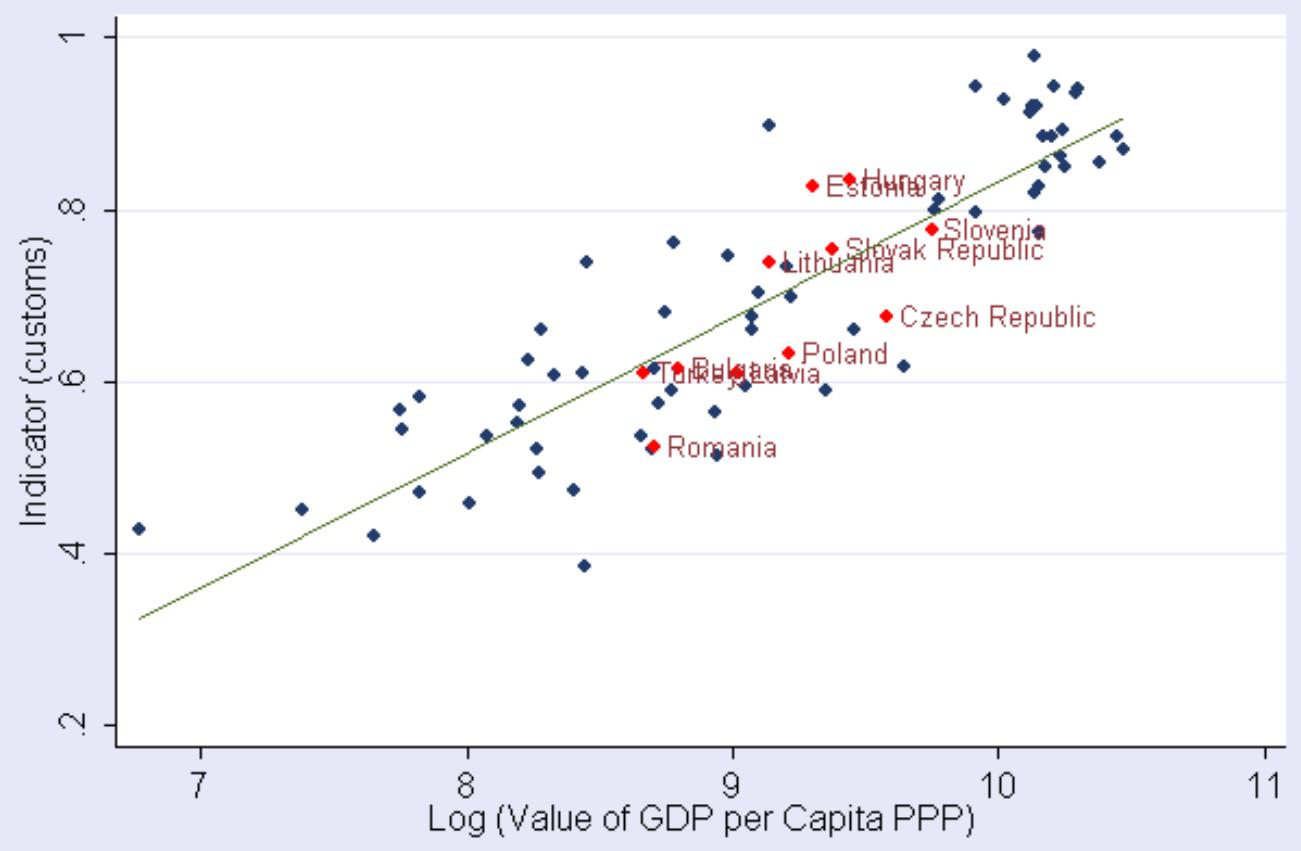

Figure 4c - Benchmarking to the value of GDP per capita (regulatory policy)

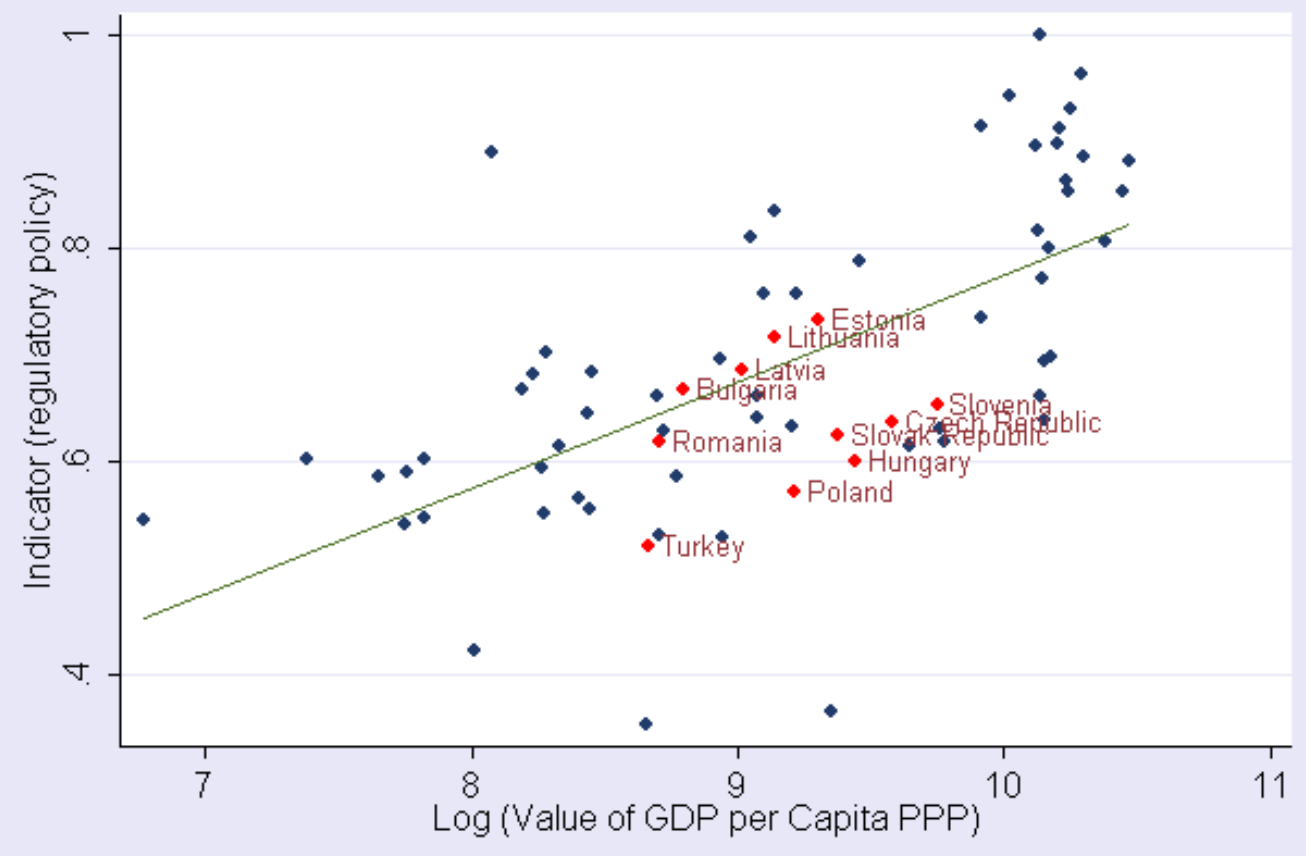




\section{Figure 4d - Benchmarking with respect to the value of GDP per capita (Information Technology infrastructure)}

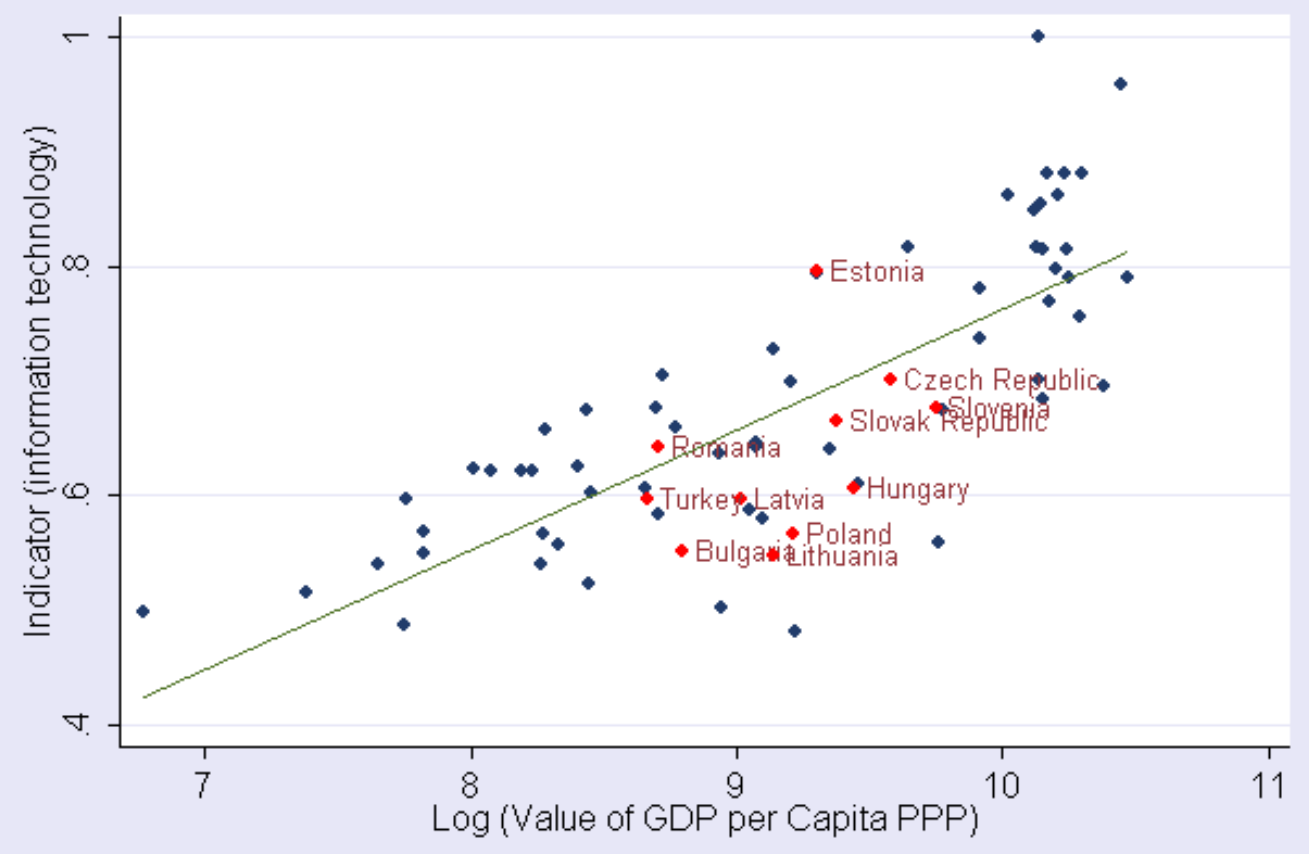

Does Trade Facilitation Promote Economic Growth? Our analysis also suggests that barriers to trade facilitation in the new and candidate EU members weaken their development potential. For example, export growth is one of the most important factors that contributed to recent economic growth in the Czech Republic, Hungary, and Poland -- the three largest economies in EU8. If infrastructure is upgraded and transactions costs lowered, trade volumes can expand. Expanded trade can also contribute to the reduction of unemployment rates. ${ }^{10}$ Benefits to growth are associated with both the reduction in transport costs and the increased reliability in delivery times. In a modern economy, delivery of goods and services are highly time-sensitive, with just-in-time supplies playing an important role in enhancing productivity and private sector efficiency.

WMO (2004) develops a gravity model to examine the role of trade facilitation in bilateral trade (see annex 2 for a description of the model). Following that exercise, we

\footnotetext{
${ }^{10}$ Many of the new member and candidate countries have two-digit unemployment rate. For example, Poland and Slovak Republic has an unemployment rate over 15 percent; Czech Republic, Estonia, and Latvia over 10 percent.
} 
simulate the impact of the hypothetical improvements in port efficiency, customs regimes, regulatory policy and information technology infrastructure half-way to the benchmark level on bilateral trade flows. Our results here suggests that behind-the-border factors do play a critical role in determining bilateral trade flows, after controlling the effects of tariffs, development level, distance and regional characteristics of exporters and importers. Others factors held constant, the improvement of port efficiency, customs regimes, regulatory policy and IT infrastructure will lead to the increase of export volumes as well as import volumes.

The analysis indicates that the increase in a country's export (import) volumes engendered by higher levels of its behind-the-border indicators depends on (i) the marginal impact of the indicator in question on exports (imports), (ii) the relative improvement in this indicator, and (iii) the initial export (import) volumes. Table 1 shows that the new and candidate EU member countries are expected to have large trade gains if they raise their trade facilitation capacities to a level that is $50 \%$ of that of the EU15 average. The lower the initial trade facilitation capability of a country, the larger the improvement it is expected to make in order to reach the benchmark level (i.e., half-way to EU15 average).

Table 1 - Absolute trade gains for new and candidate EU members- Raising Capacity Half-way to the EU Average (\$ billion)

\begin{tabular}{|cccccccccc|}
\hline \hline & \multicolumn{2}{c}{ port efficiency } & \multicolumn{2}{c}{ customs regimes } & \multicolumn{2}{c|}{ regulatory policy } & \multicolumn{2}{c|}{ IT infrastructure } \\
\hline Country & export & import & export & import & export & import & export & import \\
\hline New members & & & & & & & & \\
Czech Republic & 6.55 & 2.23 & 2.23 & 2.28 & 2.48 & 1.15 & 3.53 & 1.36 \\
Estonia & 0.21 & 0.09 & 0.05 & 0.06 & 0.10 & 0.06 & NA & NA \\
Hungary & 7.99 & 2.82 & 0.33 & 0.35 & 3.03 & 1.46 & 8.29 & 3.30 \\
Latvia & 0.17 & 0.09 & 0.20 & 0.32 & 0.10 & 0.07 & 0.58 & 0.35 \\
Lithuania & 0.60 & 0.29 & 0.15 & 0.22 & 0.12 & 0.08 & 1.46 & 0.79 \\
Poland & 6.61 & 2.91 & 3.07 & 4.07 & 4.13 & 2.48 & 12.51 & 6.22 \\
Slovakia & 5.32 & 1.87 & 0.44 & 0.47 & 1.00 & 0.48 & 1.98 & 0.79 \\
Slovenia & 1.11 & 0.37 & 0.27 & 0.27 & 0.62 & 0.28 & 1.35 & 0.51 \\
sub total & $\mathbf{2 8 . 5 5}$ & $\mathbf{1 0 . 6 7}$ & $\mathbf{6 . 7 4}$ & $\mathbf{8 . 0 4}$ & $\mathbf{1 1 . 5 7}$ & $\mathbf{6 . 0 6}$ & $\mathbf{2 9 . 7 0}$ & $\mathbf{1 3 . 3 1}$ \\
Candidate members & & & & & & & & \\
Bulgaria & 1.77 & 0.87 & 0.46 & 0.68 & 0.28 & 0.19 & 1.87 & 1.04 \\
Romania & 0.97 & 0.41 & 1.68 & 2.14 & 0.94 & 0.54 & 2.20 & 1.05 \\
Turkey & 3.97 & 1.46 & 3.15 & 3.49 & 5.06 & 2.54 & 9.13 & 3.80 \\
sub total & $\mathbf{6 . 7 1}$ & $\mathbf{2 . 7 4}$ & $\mathbf{5 . 2 9}$ & $\mathbf{6 . 3 1}$ & $\mathbf{6 . 2 7}$ & 3.27 & $\mathbf{1 3 . 2 0}$ & $\mathbf{5 . 8 9}$ \\
TOTAL & $\mathbf{3 5 . 2 6}$ & $\mathbf{1 3 . 4 1}$ & $\mathbf{1 2 . 0 3}$ & $\mathbf{1 4 . 3 5}$ & $\mathbf{1 7 . 8 4}$ & $\mathbf{9 . 3 3}$ & $\mathbf{4 2 . 9 0}$ & $\mathbf{1 9 . 2 1}$ \\
\hline \hline
\end{tabular}

Note: The IT infrastructure indicator for Estonia is higher than the average of EU 1. We do not display trade gains here. 
Our results show that more gains in exports than in imports are expected should the values of three out of the four indicators (port efficiency, regulatory regimes and IT infrastructures) of the new and candidate member countries improve halfway to the EU15 average. They would expect large trade gains as well as improvements in trade balances as their integration into the EU continues. For example, the greatest absolute trade gains - \$49 billion and \$62 billion respectively - could be expected if their port efficiency and IT infrastructure reach half-way the average level of EU, and $70 \%$ of trade gains are associated with export expansion. It suggests that unilateral reforms in trade facilitation are not necessarily net import enhancing. Trade facilitation improvements can be, over time, to some extent self-financing.

Table 2 shows that improvements in behind-the-border factors also result in large relative trade gains. Such gains reach around $11 \%$ if the capacity of the new and candidate EU members reach halfway the EU-15 average. For instance, Lithuania's trade volume rises more than 25\% if its IT infrastructure level reaches 50\% of the EU level.

Table 2 - Relative Trade Gains of New and Candidate EU Members- Raising Capacity Half-Way to the EU Level

\begin{tabular}{|ccccc|}
\hline \hline & port efficiency & customs regimes & regulatory policy & IT infrastructure \\
\hline New members & & & & \\
Czech Republic & $13.40 \%$ & $6.87 \%$ & $5.54 \%$ & $7.46 \%$ \\
Estonia & $3.34 \%$ & $1.30 \%$ & $1.80 \%$ & NA \\
Hungary & $17.46 \%$ & $1.09 \%$ & $7.25 \%$ & $18.73 \%$ \\
Latvia & $5.03 \%$ & $10.22 \%$ & $3.29 \%$ & $18.28 \%$ \\
Lithuania & $10.31 \%$ & $4.33 \%$ & $2.28 \%$ & $26.13 \%$ \\
Poland & $12.01 \%$ & $9.01 \%$ & $8.34 \%$ & $23.63 \%$ \\
Slovakia & $29.56 \%$ & $3.73 \%$ & $6.06 \%$ & $11.37 \%$ \\
Slovenia & $8.05 \%$ & $2.94 \%$ & $4.89 \%$ & $10.10 \%$ \\
sub total average & $\mathbf{1 2 . 4 0 \%}$ & $\mathbf{4 . 9 4 \%}$ & $\mathbf{4 . 9 3 \%}$ & $\mathbf{1 6 . 5 3 \%}$ \\
Candidate members & & & & \\
Bulgaria & $22.81 \%$ & $9.89 \%$ & $3.99 \%$ & $25.16 \%$ \\
Romania & $5.71 \%$ & $15.74 \%$ & $6.11 \%$ & $13.40 \%$ \\
Turkey & $8.34 \%$ & $10.19 \%$ & $11.68 \%$ & $19.86 \%$ \\
sub total average & $\mathbf{1 2 . 2 9 \%}$ & $\mathbf{1 1 . 9 4 \%}$ & $\mathbf{7 . 2 6 \%}$ & $\mathbf{1 9 . 4 8 \%}$ \\
AVERAGE & $\mathbf{1 2 . 3 7 \%}$ & $\mathbf{6 . 8 5 \%}$ & $\mathbf{5 . 5 7 \%}$ & $\mathbf{1 7 . 4 1 \%}$ \\
\hline \hline
\end{tabular}

Note: The IT infrastructure development level of Estonia is higher than the average of EU 15, so its trade gains are not displayed here. 


\section{Externalities from Investment in Trade Facilitation}

Trade facilitation improvements benefit not only the countries that implement them, but also their trading partners. The more intense are trade relations between countries, the greater the benefit partner countries will enjoy should one (or more) of the countries improve its trade facilitation regime, all others being equal. Given the importance of intra-regional trade between the EU15 and the new and candidate EU members, the expected gains to the former resulting from the trade facilitation improvements in the latter will likely be significant.

Table 3 shows that if all four dimensions of trade facilitation for each of the new member (EU8) and candidate member countries (Bulgaria, Romania, and Turkey) improve up to half-way the EU15 level, almost $\$ 10$ billion trade gains will be expected for the EU15, the EU8, and the three candidate members as a whole in 2001. ${ }^{11}$ Among the total gains for trading partner countries, $\$ 2.7$ billion (or $28 \%$ ) comes from their export gains, and $\$ 6.9$ billion (or 72\%) come from their import gains (Table 3, Table 4). In other words, if the trade facilitation capacity of new and candidate EU members improve measurably, their trade volumes with other European countries will also increase; in particular, partner countries will increase their volumes of imports from the improving countries by a larger margin than partner exports increase to those countries. ${ }^{12}$

These findings echo our argument that trade facilitation improvements in new and candidate EU member countries will strongly increase their intra-regional trade with the EU15. The trade gains for the EU15 represent 74\% of the total trade gains for all European

\footnotetext{
${ }^{11}$ Here, we use the data of bilateral import volume of Bulgaria from EU15, other EU8 countries, Romania and Turkey in 2000 since the data in 2001 is not available. As argued above, the IT infrastructure development level of Estonia is better than the EU15 average, we neglect the IT infrastructure improvement in Estonia. That is to say, we suppose that no improvements of IT infrastructure occur in Estonia. When we simulate the trade gain of a EU8 or a candidate member country resulting from the EU8 or candidate member countries, we neglect the trade gain of the country in question. In other words, we simulate the trade gain on the other EU8 countries (or other candidate member countries) resulting from the improvement of trade facilitation in the new or candidate member country in question.

12 The reason for the higher import gains for partner countries stems from a higher elasticity of export to trade facilitation improvement than the corresponding elasticity for imports, as found by WMO (2004). This implies that if a country improves its trade facilitation, its export volume increase will be higher than its import volume increase.
} 
countries as a whole, among which the import gains for EU15 represent 54\% of the total gains.

Among the four dimensions of trade facilitation, improvement of IT infrastructure will result in the highest trade gains (more than \$4 billion), which is greater than the gains from improvement in port efficiency (with trade gains approaching \$3 billion). Improvements in regulatory policy and customs regimes share quasi-equally trade gains of around $\$ 1.5$ billion each. In other words, more than $40 \%$ of the trade gains come from improvements in IT infrastructure and almost 30\% from port efficiency. This suggests that a higher priority for improvement be accorded to IT infrastructure and port efficiency for new and candidate EU members. The acquis communautaire may play an important role in getting the customs and regulatory indicators to higher standards for the new members versus the candidate countries.

Tables 5a-d detail the trade gains for the EU15, EU8 and three candidate member countries resulting from different types of trade facilitation improvements by each new and candidate member country in absolute terms, respectively. It is not surprising that there are large trade gains from trade facilitation improvements by the Czech Republic, Hungary, and Poland given their large economic size. The larger the improvement one country makes in trade facilitation, the larger the trade gains. For a large country like Poland which the data suggest requires significant improvements in trade facilitation, significant progress is required to approach half-way the level of the EU15.

Tables 6a-d show the corresponding relative trade gains. The results show that, in contrast to the large absolute trade gains that the EU15 will enjoy due to improvements in trade facilitation by the EU8 and candidate member countries, it is the two latter groups of countries that will benefit the most relative to their own trade volumes. In particular, the relative trade gains of the partner EU8 and candidate member countries are quite large should the three largest of these economies (Czech Republic, Hungary, and Poland) improve their trade facilitation. For example, if Poland increases its IT infrastructure to half-way the EU15 average, the other 7 new member countries will enjoy a trade gain of $0.8 \%$ (of which the export gain is $0.5 \%$ and the import gain is $1.0 \%$ ), and the three candidate member countries will enjoy a trade gain of $0.25 \%$ (of which the export gain is $0.16 \%$ and import gain is $0.33 \%$ ), while the EU15 enjoy a trade gain of $0.29 \%$ (of which the export gain is $0.19 \%$ and 
the import gain is $0.39 \%$ ). This suggests that trade facilitation improvements by the new and candidate EU members will largely increase the trade volumes among themselves, thanks to the relatively intense trade relationships among them.

Table 3 Absolute trade gains of European partner countries resulted from trade facilitation improvements of the new and candidate member countries (unit: million \$)

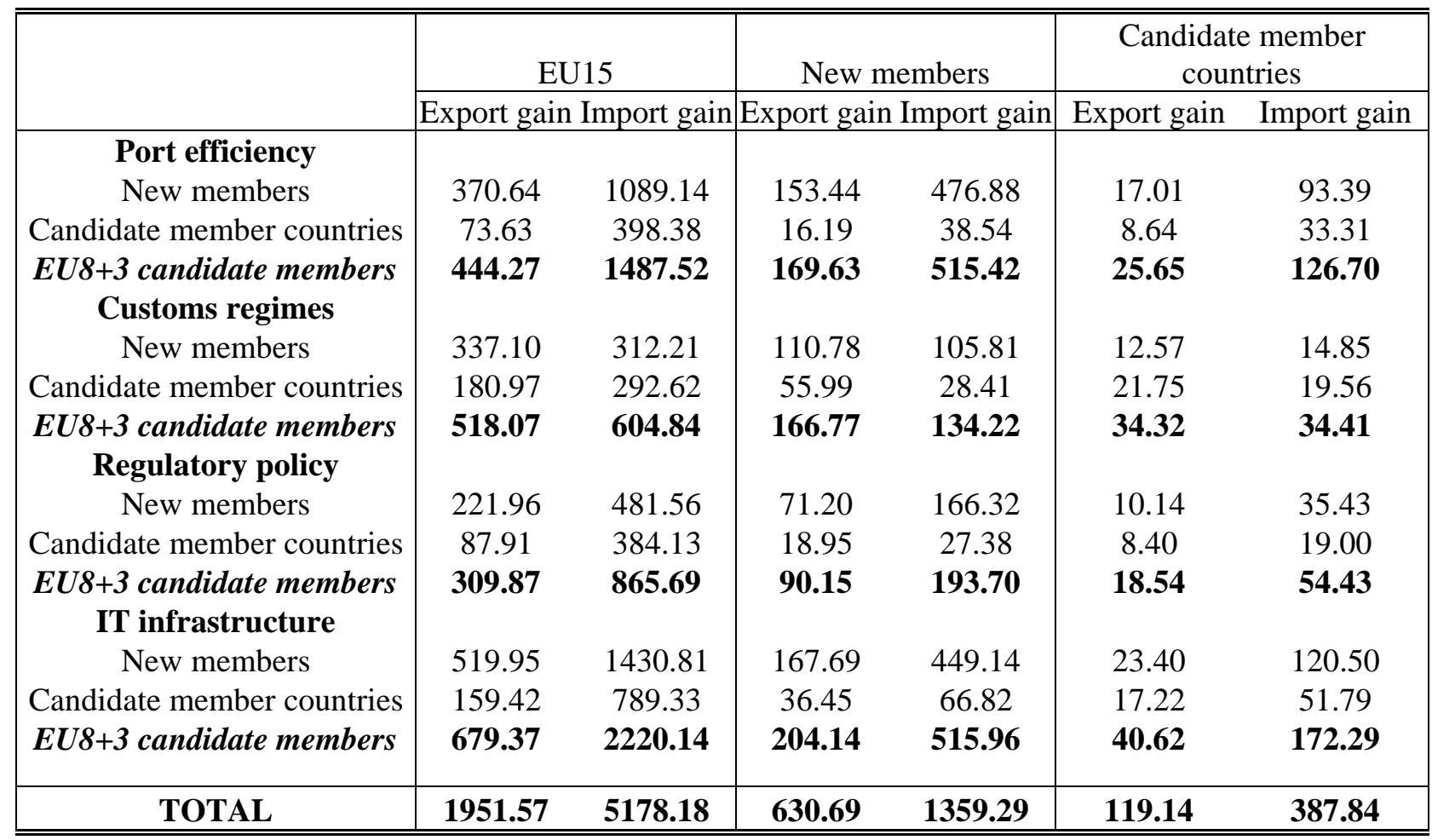


Table 4 Relative trade gains of European partner countries resulted from trade facilitation improvements of the new member and candidate member countries

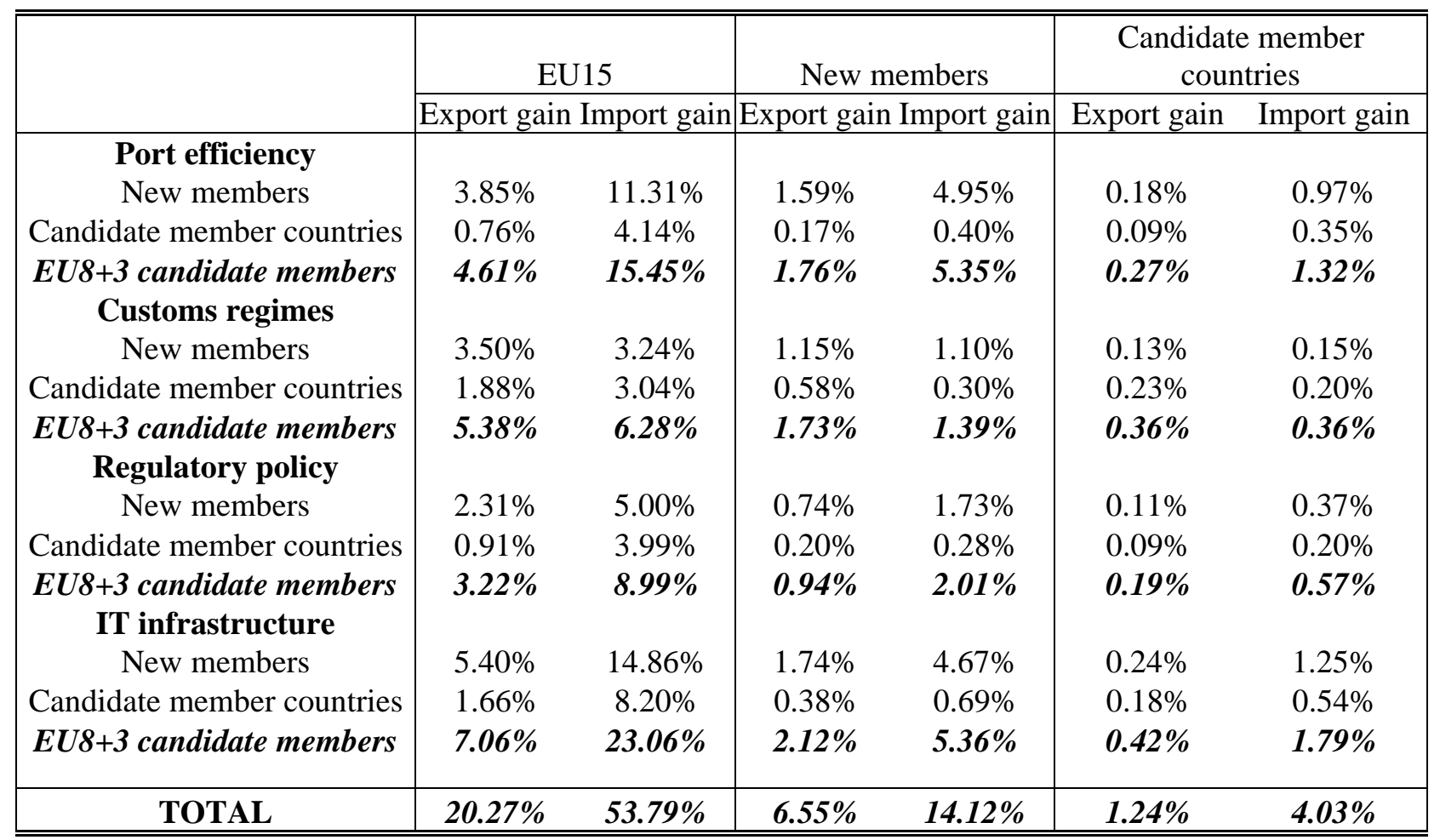

Table 5a Absolute trade gains of European partner countries resulted from port efficiency improvement (half-way to EU15) of each new member and candidate member countries (unit: million \$)

\begin{tabular}{|c|cc|cc|cc|}
\hline \hline \multirow{3}{*}{ Port efficiency } & \multicolumn{3}{|c|}{ EU15 } & \multicolumn{2}{c|}{ New members } & \multicolumn{2}{c|}{$\begin{array}{c}\text { Candidate member } \\
\text { countries }\end{array}$} \\
\cline { 2 - 7 } & Export gain & Import gain & Export gain Import gain & Export gain Import gain \\
\hline New members & & & & & & \\
Czech Republic & 1445.73 & 4254.22 & 228.14 & 928.23 & 16.64 & 102.77 \\
Estonia & 46.59 & 122.28 & 7.32 & 22.14 & 0.49 & 0.28 \\
Hungary & 1644.67 & 5442.06 & 165.69 & 536.00 & 46.82 & 216.90 \\
Latvia & 51.10 & 104.90 & 20.12 & 34.45 & 0.76 & 0.08 \\
Lithuania & 166.00 & 300.69 & 53.45 & 69.88 & 1.89 & 14.05 \\
Poland & 1880.95 & 4141.78 & 212.69 & 552.59 & 34.39 & 95.11 \\
Slovakia & 1068.83 & 3096.13 & 419.32 & 1235.44 & 14.21 & 99.19 \\
Slovenia & 249.54 & 625.13 & 28.39 & 87.41 & 4.43 & 17.19 \\
subtotal & $\mathbf{6 5 5 3 . 4 3}$ & $\mathbf{1 8 0 8 7 . 2 0}$ & $\mathbf{1 1 3 5 . 1 1}$ & $\mathbf{3 4 6 6 . 1 2}$ & $\mathbf{1 1 9 . 6 3}$ & $\mathbf{5 4 5 . 5 6}$ \\
Bundidate member countries & & & & & & \\
Romania & 345.14 & 977.98 & 39.71 & 56.93 & 30.13 & 94.94 \\
Turkey & 260.93 & 719.21 & 39.33 & 47.92 & 13.37 & 35.79 \\
subtotal & 735.15 & 2198.22 & 27.75 & 119.22 & 21.53 & 69.61 \\
TOTAL & $\mathbf{1 3 4 1 . 2 2}$ & $\mathbf{3 8 9 5 . 4 1}$ & $\mathbf{1 0 6 . 8 0}$ & $\mathbf{2 2 4 . 0 6}$ & $\mathbf{6 5 . 0 3}$ & $\mathbf{2 0 0 . 3 4}$ \\
\hline \hline
\end{tabular}


Table 5b Absolute trade gains of European partner countries resulted from customs regimes improvement (half-way to EU15) of each new member and candidate member countries (unit: million \$)

\begin{tabular}{|c|cc|cc|cc|}
\hline \hline \multirow{2}{*}{ Customs regimes } & \multicolumn{3}{|c|}{ EU15 } & \multicolumn{2}{c|}{ New members } & \multicolumn{2}{c|}{$\begin{array}{c}\text { Candidate member } \\
\text { countries }\end{array}$} \\
\cline { 2 - 7 } & \multicolumn{2}{|c|}{ Export gain } & Import gain & Export gain Import gain & Export gain Import gain \\
\hline New members & & & & & & \\
Czech Republic & 1477.70 & 1444.72 & 233.18 & 315.22 & 17.01 & 34.90 \\
Estonia & 34.19 & 29.81 & 5.37 & 5.40 & 0.36 & 0.07 \\
Hungary & 203.11 & 223.30 & 20.46 & 21.99 & 5.78 & 8.90 \\
Latvia & 184.39 & 125.76 & 72.58 & 41.30 & 2.74 & 0.10 \\
Lithuania & 127.25 & 76.58 & 40.97 & 17.80 & 1.45 & 3.58 \\
Poland & 2631.62 & 1925.30 & 297.57 & 256.87 & 48.11 & 44.21 \\
Slovakia & 266.40 & 256.40 & 104.52 & 102.31 & 3.54 & 8.21 \\
Slovenia & 182.31 & 151.74 & 20.74 & 21.22 & 3.23 & 4.17 \\
subtotal & 5106.97 & 4233.62 & 795.39 & 782.11 & 82.22 & 104.14 \\
Bulgaria & & & & & & \\
Romania & 270.77 & 254.92 & 31.16 & 14.84 & 23.64 & 24.75 \\
Turkey & 1356.64 & 1242.38 & 204.50 & 82.77 & 69.49 & 61.83 \\
subtotal & 1755.39 & 1743.95 & 66.27 & 94.58 & 51.40 & 55.22 \\
TOTAL & 3382.79 & 3241.25 & 301.93 & 192.19 & 144.53 & 141.80 \\
\hline \hline
\end{tabular}


Table 5c Absolute trade gains of European partner countries resulted from regulatory policy improvement (half-way to EU15) of each new member and candidate member countries (unit: million \$)

\begin{tabular}{|c|cc|cc|cc|}
\hline \hline \multirow{3}{*}{ Regulatory policy } & \multicolumn{3}{|c|}{} & \multicolumn{2}{c|}{ NU15 } & \multicolumn{2}{c|}{$\begin{array}{c}\text { Candidate member } \\
\text { countries }\end{array}$} \\
\cline { 2 - 7 } & \multicolumn{2}{|c|}{ Export gain Import gain } & Export gain Import gain & Export gain Import gain \\
\hline New members & & & & & & \\
Czech Republic & 746.96 & 1611.31 & 117.87 & 351.57 & 8.60 & 38.92 \\
Estonia & 30.99 & 59.62 & 4.87 & 10.79 & 0.33 & 0.14 \\
Hungary & 850.51 & 2063.06 & 85.68 & 203.19 & 24.21 & 82.23 \\
Latvia & 40.54 & 61.00 & 15.96 & 20.03 & 0.60 & 0.05 \\
Lithuania & 44.84 & 59.55 & 14.44 & 13.84 & 0.51 & 2.78 \\
Poland & 1602.45 & 2586.69 & 181.20 & 345.11 & 29.29 & 59.40 \\
Slovakia & 272.83 & 579.37 & 107.04 & 231.18 & 3.63 & 18.56 \\
Slovenia & 189.25 & 347.55 & 21.53 & 48.60 & 3.36 & 9.56 \\
Subtotal & $\mathbf{3 7 7 8 . 3 6}$ & $\mathbf{7 3 6 8 . 1 5}$ & $\mathbf{5 4 8 . 5 8}$ & $\mathbf{1 2 2 4 . 3 2}$ & $\mathbf{7 0 . 5 3}$ & $\mathbf{2 1 1 . 6 3}$ \\
Bulgaria & & & & & & \\
Romania & 73.46 & 152.59 & 8.45 & 8.88 & 6.41 & 14.81 \\
Turkey & 343.71 & 694.49 & 51.81 & 46.27 & 17.60 & 34.56 \\
Subtotal & 1279.26 & $\mathbf{2 8 0 4 . 1 8}$ & 48.30 & 152.08 & 37.46 & 88.80 \\
TOTAL & $\mathbf{1 6 9 6 . 4 3}$ & $\mathbf{3 6 5 1 . 2 6}$ & $\mathbf{1 0 8 . 5 6}$ & $\mathbf{2 0 7 . 2 3}$ & $\mathbf{6 1 . 4 8}$ & $\mathbf{1 3 8 . 1 7}$ \\
\hline \hline
\end{tabular}

Table 5d Absolute trade gains of European partner countries resulted from IT infrastructure improvement (half-way to EU15) of each new member and candidate member countries (unit: million \$)

\begin{tabular}{|c|cc|cc|cc|}
\hline \hline \multirow{3}{*}{ IT infrastructure } & \multicolumn{3}{|c|}{} & \multicolumn{2}{c|}{$\begin{array}{c}\text { Candidate member } \\
\text { countries }\end{array}$} \\
\cline { 2 - 7 } & \multicolumn{2}{|c|}{ EU15 } & \multicolumn{2}{c|}{ New members } & \multicolumn{2}{c|}{ Export gain Import gain } \\
\cline { 2 - 7 } New members & & & & & \\
Czech Republic & 880.45 & 2294.29 & 138.94 & 500.59 & 10.13 & 55.42 \\
Estonia & NA & NA & NA & NA & NA & NA \\
Hungary & 1926.69 & 5645.56 & 194.10 & 556.04 & 54.85 & 225.02 \\
Latvia & 200.72 & 364.88 & 79.01 & 119.82 & 2.98 & 0.28 \\
Lithuania & 456.31 & 731.97 & 146.92 & 170.10 & 5.19 & 34.19 \\
Poland & 4020.49 & 7839.71 & 454.62 & 1045.96 & 73.50 & 180.02 \\
Slovakia & 449.16 & 1152.18 & 176.21 & 459.75 & 5.97 & 36.91 \\
Slovenia & 342.45 & 759.69 & 38.96 & 106.23 & 6.07 & 20.89 \\
subtotal & $\mathbf{8 2 7 6 . 2 7}$ & $\mathbf{1 8 7 8 8 . 2 7}$ & $\mathbf{1 2 2 8 . 7 7}$ & $\mathbf{2 9 5 8 . 4 9}$ & $\mathbf{1 5 8 . 7 1}$ & 552.73 \\
Bulgaria & & & & & & \\
Romania & 412.26 & 1034.49 & 47.44 & 60.22 & 36.00 & 100.43 \\
Turkey & 666.29 & 1626.30 & 100.44 & 108.35 & 34.13 & 80.93 \\
subtotal & 1911.45 & 5061.39 & 72.16 & 274.50 & 55.97 & 160.27 \\
TOTAL & $\mathbf{2 9 9 0 . 0 1}$ & $\mathbf{7 7 2 2 . 1 9}$ & $\mathbf{2 2 0 . 0 4}$ & $\mathbf{4 4 3 . 0 7}$ & $\mathbf{1 2 6 . 1 0}$ & $\mathbf{3 4 1 . 6 3}$ \\
\hline \hline
\end{tabular}


Table 6a Trade gains of European partner countries (relative to their respective total trade volume) resulted from port efficiency improvement (half-way to EU15) of each new member and candidate member countries

\begin{tabular}{|c|ccc|ccc|ccc|}
\hline \hline \multirow{2}{*}{ Port Efficiency } & \multicolumn{4}{|c|}{ EU15 } & \multicolumn{3}{c|}{ New members } & \multicolumn{3}{c|}{ Candidate member countries } \\
\cline { 2 - 10 } & \multicolumn{3}{|c|}{ Export gain Import gain Trade gains } & Export gain Import gain Trade gains & Export gain Import gain & Trade gains \\
\hline Czech & & & & & & & & & \\
Republic & 6.75 & 21.30 & 13.77 & 24.16 & 82.94 & 56.04 & 3.60 & 18.78 & 11.83 \\
Estonia & 0.22 & 0.61 & 0.41 & 0.60 & 1.58 & 1.12 & 0.11 & 0.05 & 0.08 \\
Hungary & 7.68 & 27.25 & 17.13 & 17.12 & 47.33 & 33.41 & 10.14 & 39.64 & 26.13 \\
Latvia & 0.24 & 0.53 & 0.38 & 1.61 & 2.43 & 2.05 & 0.16 & 0.01 & 0.08 \\
Lithuania & 0.78 & 1.51 & 1.13 & 4.34 & 4.99 & 4.68 & 0.41 & 2.57 & 1.58 \\
Poland & 8.79 & 20.74 & 14.55 & 22.94 & 55.31 & 39.73 & 7.44 & 17.38 & 12.83 \\
Slovakia & 4.99 & 15.50 & 10.06 & 36.47 & 93.18 & 66.84 & 3.08 & 18.13 & 11.24 \\
Slovenia & 1.17 & 3.13 & 2.11 & 2.41 & 6.44 & 4.57 & 0.96 & 3.14 & 2.14 \\
Bulgaria & 1.61 & 4.90 & 3.20 & 3.13 & 3.92 & 3.55 & 7.25 & 19.86 & 14.00 \\
Romania & 1.22 & 3.60 & 2.37 & 3.10 & 3.30 & 3.21 & 3.76 & 8.70 & 6.41 \\
Turkey & 3.43 & 11.01 & 7.09 & 2.19 & 8.22 & 5.41 & 14.04 & 33.98 & 25.44 \\
\hline \hline
\end{tabular}

Note: Figures are presented in 1/10000. For example, if the port efficiency development level of the Czech Republic reaches half-way of EU15 average, the export volume of EU15 will increase 0.000675.

Table 6b Relative trade gains of European partner countries (relative to their respective total trade volume) resulted from customs regimes improvement (half-way to EU15) of each new member and candidate member countries

\begin{tabular}{|c|c|c|c|c|c|c|c|c|c|}
\hline \multirow[t]{2}{*}{$\begin{array}{l}\text { Customs } \\
\text { regimes }\end{array}$} & \multicolumn{3}{|c|}{ EU15 } & \multicolumn{3}{|c|}{ New members } & \multicolumn{3}{|c|}{ Candidate member countries } \\
\hline & Export gai & nport ga & rade gains & Export gai & nport ga & Trade gains & Export gai & nport gain & Trade gains \\
\hline Republic & 6.90 & 7.23 & 7.06 & 24.70 & 28.17 & 26.58 & 3.68 & 6.38 & 5.14 \\
\hline Estonia & 0.16 & 0.15 & 0.15 & 0.44 & 0.38 & 0.41 & 0.08 & 0.01 & 0.04 \\
\hline Hungary & 0.95 & 1.12 & 1.03 & 2.11 & 1.94 & 2.02 & 1.25 & 1.63 & 1.45 \\
\hline Latvia & 0.86 & 0.63 & 0.75 & 5.81 & 2.91 & 4.27 & 0.59 & 0.02 & 0.28 \\
\hline Lithuania & 0.59 & 0.38 & 0.49 & 3.32 & 1.27 & 2.23 & 0.31 & 0.65 & 0.50 \\
\hline Poland & 12.29 & 9.64 & 11.01 & 32.10 & 25.71 & 28.78 & 10.41 & 8.08 & 9.15 \\
\hline Slovakia & 1.24 & 1.28 & 1.26 & 9.09 & 7.72 & 8.35 & 0.77 & 1.50 & 1.16 \\
\hline Slovenia & 0.85 & 0.76 & 0.81 & 1.76 & 1.56 & 1.66 & 0.70 & 0.76 & 0.73 \\
\hline Bulgaria & 1.26 & 1.28 & 1.27 & 2.46 & 1.02 & 1.69 & 5.69 & 5.18 & 5.42 \\
\hline Romania & 6.34 & 6.22 & 6.28 & 16.13 & 5.70 & 10.57 & 19.56 & 15.03 & 17.13 \\
\hline Turkey & 8.20 & 8.73 & 8.46 & 5.23 & 6.52 & 5.92 & 33.52 & 26.95 & 29.76 \\
\hline
\end{tabular}

Note: Figures are presented in 1/10000. For example, if the customs regimes development level of the Czech Republic reaches halfway of EU15 average, the export volume of EU15 will increase 0.000690 . 
Table 6c Relative trade gains of European partner countries (relative to their respective total trade volume) resulted from regulatory policy improvement (half-way to EU15) of each new member and candidate member countries on their exports and imports

\begin{tabular}{|c|ccc|ccc|ccc|}
\hline \hline \multirow{2}{*}{$\begin{array}{c}\text { Regulatory } \\
\text { policy }\end{array}$} & \multicolumn{3}{|c|}{ EU15 } & \multicolumn{3}{|c|}{ New members } & \multicolumn{2}{c|}{ Candidate member countries } \\
\cline { 2 - 9 } & \multicolumn{3}{|c|}{ Export gain Import gain Trade gains } & Export gain Import gain Trade gains & Export gain Import gain Trade gains \\
\hline Czech & & & & & & & & \\
Republic & 3.49 & 8.07 & 5.70 & 12.48 & 31.41 & 22.75 & 1.86 & 7.11 & 4.71 \\
Estonia & 0.14 & 0.30 & 0.22 & 0.40 & 0.77 & 0.60 & 0.07 & 0.02 & 0.05 \\
Hungary & 3.97 & 10.33 & 7.04 & 8.85 & 17.94 & 13.75 & 5.24 & 15.03 & 10.55 \\
Latvia & 0.19 & 0.31 & 0.25 & 1.28 & 1.41 & 1.35 & 0.13 & 0.01 & 0.06 \\
Lithuania & 0.21 & 0.30 & 0.25 & 1.17 & 0.99 & 1.07 & 0.11 & 0.51 & 0.33 \\
Poland & 7.49 & 12.95 & 10.12 & 19.55 & 34.54 & 27.32 & 6.34 & 10.85 & 8.79 \\
Slovakia & 1.27 & 2.90 & 2.06 & 9.31 & 17.44 & 13.66 & 0.79 & 3.39 & 2.20 \\
Slovenia & 0.88 & 1.74 & 1.30 & 1.83 & 3.58 & 2.77 & 0.73 & 1.75 & 1.28 \\
Bulgaria & 0.34 & 0.76 & 0.55 & 0.67 & 0.61 & 0.64 & 1.54 & 3.10 & 2.38 \\
Romania & 1.61 & 3.48 & 2.51 & 4.09 & 3.19 & 3.61 & 4.96 & 8.40 & 6.80 \\
Turkey & 5.98 & 14.04 & 9.87 & 3.81 & 10.48 & 7.37 & 24.43 & 43.34 & 35.24 \\
\hline \hline
\end{tabular}

Note: Figures are presented in 1/10000. For example, if the regulatory policy development level of the Czech Republic reaches halfway of EU15 average, the export volume of EU15 will increase 0.000349.

Table 6d Relative trade gains of European partner countries (relative to their respective total trade volume) resulted from IT infrastructure improvement (half-way to EU15) of each new member and candidate member countries

\begin{tabular}{|c|ccc|ccc|ccc|}
\hline \hline \multirow{2}{*}{$\begin{array}{c}\text { IT } \\
\text { infrastructure }\end{array}$} & \multicolumn{3}{|c|}{ EU15 } & \multicolumn{3}{c|}{ New members } & \multicolumn{3}{c|}{ Candidate member countries } \\
\cline { 2 - 9 } & Export gain Import gain Trade gains & Export gain Import gain Trade gains & Export gain Import gain & Trade gains \\
\hline Czech & & & & & & & & \\
Republic & 4.11 & 11.49 & 7.67 & 14.71 & 44.73 & 30.99 & 2.19 & 10.13 & 6.50 \\
Estonia & NA & NA & NA & NA & NA & NA & NA & NA & NA \\
Hungary & 9.00 & 28.27 & 18.30 & 20.06 & 49.10 & 35.72 & 11.87 & 41.12 & 27.73 \\
Latvia & 0.94 & 1.83 & 1.37 & 6.33 & 8.44 & 7.45 & 0.65 & 0.05 & 0.32 \\
Lithuania & 2.13 & 3.66 & 2.87 & 11.92 & 12.15 & 12.04 & 1.12 & 6.25 & 3.90 \\
Poland & 18.78 & 39.25 & 28.66 & 49.04 & 104.69 & 77.90 & 15.91 & 32.90 & 25.12 \\
Slovakia & 2.10 & 5.77 & 3.87 & 15.33 & 34.68 & 25.69 & 1.29 & 6.75 & 4.25 \\
Slovenia & 1.60 & 3.80 & 2.66 & 3.31 & 7.82 & 5.73 & 1.31 & 3.82 & 2.67 \\
Bulgaria & 1.93 & 5.18 & 3.50 & 3.74 & 4.15 & 3.96 & 8.67 & 21.00 & 15.27 \\
Romania & 3.11 & 8.14 & 5.54 & 7.92 & 7.47 & 7.68 & 9.61 & 19.67 & 15.01 \\
Turkey & 8.93 & 25.34 & 16.85 & 5.69 & 18.92 & 12.75 & 36.50 & 78.23 & 60.37 \\
\hline \hline
\end{tabular}

Note: Figures are presented in 1/10000. For example, if the IT infrastructure development level of the Czech Republic reaches half-way of EU15 average, the export volume of EU15 will increase 0.000411. 


\section{Concluding Remarks - Informing Capacity-Building Policy Priorities}

Our results suggest that trade gains are positively correlated with the development of behind-the-border trade facilitation capacity. Of course, projected trade gains depend on a number of other factors, such as sensitivity of trade volumes to changes in specific behindthe-border barriers and the overall structure of trade of the country in question, among other factors. Moreover, the results presented here are subject to data constraints and this analysis provides a first step in understanding the complexities of trade facilitation in a broader context. New data sets are key to future research work in this area.

Building on the analysis in Wilson, et al. (2005), the analysis here suggests that improvement in IT infrastructure has the greatest marginal impact on trade gains among the four dimensions of trade facilitation. A long paper-based system in trade transactions is highly inefficient. The lack of cooperation between multiple border agencies results in information inconsistencies. Excessive bureaucracy, lack of transparency, and the ambiguity in regulatory interpretation can also lead to unnecessary transactions costs. If clearance procedures could be streamlined, the attendant time would be shortened and costs would be saved. According to estimates prepared under the World Bank "Trade and Transport Facilitation in Southeast Europe" (TTFSE) project; the current long waiting times at border crossings is highly inefficient and costly. If the current crossing time in Bulgaria is reduced by 25 minutes, for example, the savings on transport costs are estimated in excess of US\$5 million per year after 2005 for vehicles entering Bulgaria.

What improvements in clearance capabilities are likely to have significant payoffs? The adoption of international Electronic Data Interchange standards will enhance border efficiency by processing the e-information before actual docking and enable fast integration into the international trading community. It not only cuts down the waiting time, but also enables centralized audits for valuation of traded goods by reducing information inconsistencies. The creation of databases accessible in real time at all customs locations will support selectivity and targeting procedures, and will reduce corruption opportunities by lessening human intervention and by monitoring customs performance. The streamlining of border controls, such as the implementation of a single payment window at border crossing points and the paperless transactions for customs clearance could result in large 
cost savings. The significant costs associated with the observed deficits in trade facilitation capacities in the new and candidate members of the EU engender strong incentives for them to reallocate resources so as to achieve the maximum impact of improvements in such capacities on trade gains and economic growth.

The analysis in this paper suggests that priorities for capacity building differ with the two sets of countries examined. Among the four trade facilitation indicators, IT infrastructure improvement will lead to the largest gain for the new member countries, as well as for candidate member countries. Figure 5 shows that, if all indicators improve to half of the EU 15 level, almost 40\% trade gains will result from the improvement of IT infrastructure.

As to the trade gains that could result from improvement in the other trade facilitation activities examined, however, they differ between the new and candidate member countries. The new members of the European Union exhibit large potential gains to trade with investments in port efficiency (both air and maritime ports), which represents a third of the total trade gain. The results for the candidate members suggest more widely dispersed gains with investments in port efficiency, customs regimes and regulatory policy. Improvements in each dimension share around $20 \%$ of the total trade gains. It is important to note that our results suggest that raising capacity in trade facilitation does expand exports. The on-going negations in the Doha Development agenda, although more narrowly focused than the broader measures discussed here, can have an impact through reform measures and complimentary capacity building investments with the potential to expand global exports.

Figure 5 Relative trade gains due to the improvement of each trade facilitation indicators
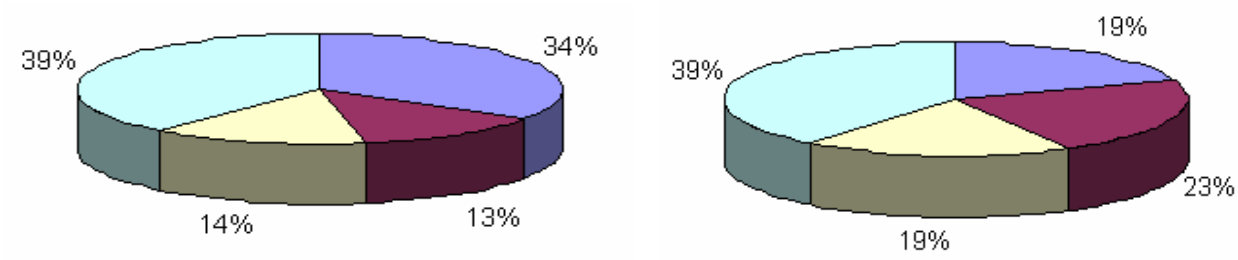

$\square$ port efficiency $\square$ customs regimes $\square$ regulatory policy $\square$ IT infrastructure

$5 a-E U 8$

5b - 3 Candidate Members 
Development planning and capacity-building programs can take these results into consideration - along with many other factors - as integration into the European Union continues. In general, improvements in port facilities and IT infrastructure are likely to be more costly than the administrative reforms at the center of customs regimes and regulatory policy -- but they can have correspondingly high payoffs. The eligibility for additional EU financing with accession should provide more scope for improvements in these areas. For the candidate member countries, such as Bulgaria and Romania that are currently negotiating the formal accession with the EU, it may be of particular interest to explore acceleration of telecommunication liberalization and investment, for example.

\section{References:}

Overman H.G., Redding S. and Venables A.J. (2001), “The Economic Geography of Trade, Production, and Income: A Survey of Empirics”, website: http://econ.lse.ac.uk/staff/ajv/hosrtv.pdf

Diamond J. (1997), “Guns, Germs, and Steel: The fates of Human Societies”, New York: W.W. Norton.

Limao N. and Venables A.J. (2001), "Infrastructure, Geographical Disadvantages, Transport Costs and Trade”, World Bank Economic Review, 15, pp.451-479.

Redding S. and Venables A.J. (2003), “Geography and Export Performance: External Market Access and Internal Supply Capacity”, website: http://econ.Ise.ac.uk/staff/ajv/Isit22.pdf

Hummels D. (1999), “Have International Transportation Costs Declined”, mimeo, website: http://www.mgmt.purdue.edu/faculty/hummelsd/

IMD (2000), World Competitiveness Yearbook. IMD: Lausanne.

Kaufmann D, Kraay A. and Zoido-Lobaton P.(2002), “Governance Matters II: Updated Indicators for 2000-01” World Bank Working Paper \#2772, The World Bank, Washington, D.C..

McCallum J (1995), "National borders matters: Canada-U.S. regional trade patterns", American Economic Review, Vol. 85, No.3, pp.615-623.

Wilson J.S., Mann C.L., and Otsuki T. (2005), “Assessing the Benefits of Trade Facilitation: A Global Perspective", The World Economy, Vol.28 Issue 6, pp. 841-871.

Wilson J.S., Mann C.L., Woo Y., Assanie N., and Choi I. (2002). Trade Facilitation: A Development Perspective in the Asia-Pacific Region. Asia Pacific Economic Cooperation: Singapore 
World Bank (2004), "Framework for World Bank Support to the European Union (EU) New Member Countries of Central and Eastern Europe", World Bank mimeo 29135.

World Economic Forum (2000). Global Competitiveness Report. World Economic Forum: Geneva. Woo Y.P. and Wilson J.S.(2000). Cutting Through Red Tape: New Directions for APEC's Trade Facilitation Agenda. Asia Pacific Foundation of Canada: Vancouver. 


\section{Annex 1: Summary Statistics for Values of Trade Facilitation Indicators}

\begin{tabular}{|c|c|c|c|c|c|c|c|c|}
\hline Category & Indexed inputs & Source & Mean & $\begin{array}{l}\text { Std. } \\
\text { Dev. }\end{array}$ & Min & $\begin{array}{c}\text { Min. } \\
\text { Importer }\end{array}$ & Max & $\begin{array}{c}\text { Max. } \\
\text { Importer }\end{array}$ \\
\hline Port Efficiency & Ports Facilities & GCR & .636 & .189 & .261 & Bolivia & 1.000 & Singapore \\
\hline & Air Transport & GCR & .710 & .166 & .229 & $\begin{array}{c}\text { Slovak } \\
\text { Republic }\end{array}$ & 1.000 & Singapore \\
\hline Aggregate Index & & & .673 & .169 & .345 & Bolivia & 1.000 & Singapore \\
\hline Customs Regimes & Hidden Import Barriers & GCR & .702 & .167 & .368 & Paraguay & 1.000 & Finland \\
\hline & Bribery & GCR & .689 & .175 & .343 & Bangladesh & 1.000 & Iceland \\
\hline Aggregate Index & & & .695 & .163 & 384 & Paraguay & 0.979 & Finland \\
\hline Regulatory Policy & $\begin{array}{l}\text { Transparency of Government } \\
\text { Policies }\end{array}$ & WCY & .619 & .205 & .089 & Argentina & 1.000 & Finland \\
\hline & Control of Corruption & KKZ & .746 & .140 & .530 & $\begin{array}{l}\text { South } \\
\text { Africa }\end{array}$ & 1.000 & Finland \\
\hline Aggregate Index & & & .689 & .139 & 353 & Venezuela & 1.000 & Finland \\
\hline \begin{tabular}{l|} 
Information Technology \\
Infrastructure
\end{tabular} & $\begin{array}{l}\text { Speed and Costs of Internet } \\
\text { Access }\end{array}$ & GCR & .629 & 162 & .348 & Vietnam & 1.000 & Finland \\
\hline & $\begin{array}{l}\text { Effect on Internet on } \\
\text { Business }\end{array}$ & GCR & .719 & .102 & .481 & Greece & 1.000 & Finland \\
\hline Aggregate Index & & & .674 & .121 & .482 & Mauritius & 1.000 & Finland \\
\hline
\end{tabular}

Source:, Mann and Otsuki (2005).

Data are from the World Economic Forum, Global Competitiveness Report, 2001-02 (GCR), IMD Lausanne, World Competitiveness Yearbook 2000 (WCY), and Kaufmann, Kraay and ZoidoLobaton (2002) (KKZ). All survey data in GCR comes from the World Economic Forum's Executive Opinion Survey. A total of 4022 firms were surveyed. "In order to provide the basis for a comparative assessment on a global basis, it is essential that we interview a sufficient number of senior business leaders in individual countries and that the sample in each country is not biased in favor of any particular business group. We have taken a number of steps to ensure this. First, we have asked each of our partner institutes, the organizations that administer the surveys in each country, to start with a comprehensive register of firms. From this, they were asked to choose a sample whose distribution across economic sectors was proportional to the distribution of the country's labor force across sectors, excluding agriculture. They were then asked to choose firms randomly within these broad sectors (for example, by choosing firms at regular intervals from an alphabetic list), and to pursue face-to-face interviews, following up for clarifications where necessary. The employment distribution was taken from data in the 1998 Yearbook of Labour Statistics of the International Labour Office. The respondents to the survey are typically a company's CEO or a member of its senior management.”

The WCY uses a 115 question survey sent to executives in top and middle management of firms in all 49 countries of the WCY. The sample size of each country is proportional to GDP, and firms "normally have an international dimension." The firms are selected to be a cross section of manufacturing, service, and primary industries. There were 3532 responses to the Survey.

KKZ (2002) updates the data on governance that were developed in Kaufmann, Kraay and Zoido-Lobaton (1999) "Governance Matters." The database contains more than 300 governance indicators for 175 countries compiled from a variety of sources in 2000/2001. Six aggregate 
indicators are constructed corresponding to six basic governance concepts: Voice and Accountability, Political Stability, Government Effectiveness, Regulatory Quality, Rule of Law and Control of Corruption.

The various raw data series were chosen because of their relevance to the four concepts of trade facilitation.

- Port efficiency" for each country $J$ is the average of two indexed inputs (all GCR):

o Port facilities and inland waterways are :(1=underdeveloped, 7=as developed as the world's best, GCR)

o Air transport is :(1=infrequent and inefficient, 7=as extensive and efficient as the world's best, GCR)

- "Customs Regimes" for each country $J$ is the average of two indexed inputs (all GCR):

o Hidden import barriers other than published tariffs and quotas

o Irregular extra payments or bribes connected with import and export permits

- "Regulatory policy" for each country $J$ is constructed as the average of four indexed inputs:

0 Transparency of government policy is satisfactory (WCY)

o Control of Corruption (KKZ)

- "Information technology infrastructures" for each country $J$ is as the average of three indexed inputs (all GCR):

0 Speed and cost of internet access are: ( $1=$ slow and expensive, $7=$ fast and cheap)

o Internet contribution to reduce inventory costs is: (1=no improvement, $7=$ huge improvement) 


\section{Annex 2: Description of the gravity model in, Mann and Otsuki (2005) 13}

, Mann and Otsuki (2005) develops the gravity equation to examine the role of trade facilitation, measured by port efficiency, customs regimes, regulatory policy and information technology infrastructure, in the determination of bilateral trade:

$$
\begin{aligned}
& \ln \left(V_{J I}^{t}\right)=b_{1} \ln \left(100+\text { TARIFF }_{J I}^{t}\right)+b_{2} \ln P E_{J}+b_{3} \ln R E_{J}+b_{4} \operatorname{lnSI} I_{J}+b_{5} \ln P E_{I}+b_{6} \ln C E_{I}+b_{7} \ln R E I_{I}+ \\
& b_{8} \ln I_{I}+b_{9} \ln \left(G N P_{I}^{t}\right)+b_{10} \ln \left(G N P_{J}^{t}\right)+b_{11} \ln \left(G N P P C_{I}^{t}\right)+b_{12} \ln \left(G N P P C_{J}^{t}\right)+b_{13} \ln \left(D_{S} T_{I J}\right)+b_{14} D_{A D J}+b_{15} \\
& D_{A S E A N}+b_{16} D_{\text {NAFTA }}+b_{17} D_{\text {LAIA }}+b_{18} D_{A U N Z}+b_{19} D_{M E R C O S U R}+b_{20} D_{E U}+b_{21} D_{E N G}+b_{22} D_{F R C}+b_{23} D_{S P N} \\
& +b_{24} D_{A R B}+b_{25} D_{C H N}+b_{26} D_{G M N}+b_{27} D_{P O R}+b_{28} D_{R U S}+b_{29} D_{2000}+\varepsilon_{J I}{ }^{t}
\end{aligned}
$$

where $I$ and $J$ stand for the importer and exporter respectively, and $t$ denotes trading years ( $t=2000$, 2001). Parameter $b$ 's are coefficients. The term $\varepsilon_{J I}{ }^{t}$ is the error term, assumed to be normally distributed with mean zero. The value of manufactures exports from country $J$ to $I$ is denoted as $V_{J I}$ (so exporter to importer) The term TARIFF $F_{J I}$ denotes applied tariff rate in the percent ad valorem term that is specific to the trading partners $I$ and $J$ and year $t$. The inclusion of the tariff variable is useful for reducing omitted variable biases. It is particularly important for some nations since unlike the EU whose tariff policies are harmonized, applied tariff rates generally vary across most other countries and possibly across their exporting partners.

The terms $P E_{J}, R E_{J}$ and $S I_{J}$ denote exporting_country $J$ 's indicators of port efficiency, regulatory policy, and information technology infrastructures. Similarly $P E_{I}, R E_{I}$ and $S I_{I}$ stand for the same trade facilitation measures in the importing country. For the importing country we include one additional measure i.e. 'Customs Regimes' or $C E_{I}$. We use 'Customs Regimes' only for the importers since in bilateral trade customs is more relevant as a factor affecting imports than exports.

This set of trade facilitation variables is different than in WMO. There, we included only $P E_{I}$, $R E_{I}, S I_{I}$, and $C E_{I}$. That is, for country $I$ we considered only the effect on imports of unilateral trade facilitation. Country I's exports improved indirectly when its trading partners improved their trade facilitation efforts. In this formulation, we take explicit account of the fact that country $J$ ' $s$ exports (as well as its imports) will improve through its own trade facilitation efforts.

The term GNP denotes gross national product and GNPPC denotes per capita GNP, where both are expressed in 1995 US dollar terms. Geographical distance between capital cities $I$ and $J$ is denoted as $D I S T_{I J}$. Dummy variables are included to capture the effect of preferential trade arrangements, language similarity and adjacency. The trade arrangements dummies include NAFTA $\left(D_{\text {NAFTA }}\right)$, ASEAN $\left(D_{\text {ASEAN }}\right)$, LAIA $\left(D_{\text {LAIA }}\right)$, AUNZ $\left(D_{\text {AUNZ }}\right)$, MERCOSUR $\left(D_{\text {MERCOSUR }}\right)$ and EU $\left(D_{\text {EU }}\right)$. The language dummies include English $\left(D_{E N G}\right)$, French $\left(D_{F R C}\right)$, Spanish $\left(D_{S P N}\right)$, Arabic $\left(D_{A R B}\right)$, Chinese $\left(D_{C H N}\right)$, German $\left(D_{G M N}\right)$, Portuguese $\left(D_{P O R}\right)$ and Russian $\left(D_{R U S}\right)$. The adjacency dummy $D_{A D J}$ takes the value of one if country $I$ is adjacent to country $J$ and zero otherwise. Additionally a dummy for year 2000 is included in the model to control for time-specific shocks.

\footnotetext{
${ }^{13}$ Source:, Mann and Otsuki (2005).
} 


\section{The estimation results are as follows:}

\begin{tabular}{|c|c|c|}
\hline & Coef. & Std. Err. \\
\hline Constant & $-10.641^{* * *}$ & 1.558 \\
\hline Tariff Rates & $-1.155^{* * *}$ & 0.318 \\
\hline Port Efficiency of Importer & $0.307 *$ & 0.163 \\
\hline Port Efficiency of Exporter & $0.924 * * *$ & 0.148 \\
\hline Customs Environment of Importer & $0.472 * *$ & 0.199 \\
\hline Regulatory Envornment of Importer & $0.281 *$ & 0.144 \\
\hline Regulatory Envornment of Exporter & $0.620 * * *$ & 0.132 \\
\hline Service-sector infrastructures of Importer & $0.729 * * *$ & 0.224 \\
\hline Service-sector infrastructures of Exporter & $1.943 * * *$ & 0.216 \\
\hline GNP of Importer & $0.915^{* * *}$ & 0.014 \\
\hline Per capita GNP of Importer & $-0.182 * * *$ & 0.037 \\
\hline GNP of Exporter & $1.246^{* * *}$ & 0.014 \\
\hline Per capita GNP of Exporter & $-0.226 * * *$ & 0.029 \\
\hline Geographical Distance & $-1.258^{* * *}$ & 0.025 \\
\hline Adjacency dummy & $0.336 * * *$ & 0.114 \\
\hline Year 2000 dummy & -0.031 & 0.039 \\
\hline Adjusted R-squared & 0.758 & \\
\hline Number of the observations & 7,904 & \\
\hline
\end{tabular}

Note: The significance levels at 10\%, 5\% and 1\% are denoted by “*”, “**”, and “***”, respectively. For the sake of simplicity, the estimations of the geographic dummies are not shown in the table. 